Article

\title{
Climate Change and Vegetation Evolution during the Transition from Marine Isotope Stage 5 to 4 Based on Two Typical Profiles at the Southern Chinese Loess Plateau
}

\author{
Tieniu $\mathrm{Wu}^{1,2}{ }^{1}$, Huaqing $\mathrm{Wu}^{1}{ }^{1}$, Henry Lin ${ }^{2}$, Tiantian $\mathrm{Yang}^{3}{ }^{3}$, Xiaoyang $\mathrm{Wu}^{1}, \mathrm{Yi} \mathrm{Jie}{ }^{1}$ and \\ Pei Tian ${ }^{1, *}$ \\ 1 Key Laboratory for Geographical Process Analysis and Simulation, Hubei Province, Central China Normal \\ University, Wuhan 430079, China; wutieniu01@mail.ccnu.edu.cn (T.W.); wuhuaqing@mails.ccnu.edu.cn (H.W.); \\ huangxinyi@mails.ccnu.edu.cn (X.W.); jieyi@mail.ccnu.edu.cn (Y.J.) \\ 2 Department of Ecosystem Science and Management, The Pennsylvania State University, University Park, \\ PA 16802, USA; yongqin2004@outlook.com \\ 3 School of Civil Engineering and Environmental Science, The University of Oklahoma, Norman, OK 73019, \\ USA; Tiantian.Yang@ou.edu \\ * Correspondence: tianpei@mail.bnu.edu.cn; Tel.: +86-27-67868305
}

Received: 9 January 2020; Accepted: 12 February 2020; Published: 13 February 2020

\begin{abstract}
The geological transitional period from the Marine Isotope Stage (MIS) 5 to 4 during the Quaternary period is a multidimensional change involving monsoon and precipitation variation, vegetation dynamics, and environmental evolution. The first loess layer (L1) and the first paleosol layer (S1) in the Chines Loess Plateau provide excellent high-resolution terrestrial sediment record for this transition. In this work, grain size (GS), $\mathrm{CaCO}_{3}$ content, magnetic susceptibility (MS), and pollen composition were measured at intervals of 2-cm in two representative L1/S1 profiles in the southern Chinese Loess Plateau to reconstruct records of climatic and vegetative changes during this transition. Our results showed that, in general, the paleo-vegetation type was forest-steppe, with Pinus being the commonest tree, and Chenopodiaceae and Artemisia being common herbs in the study area. The topography had a significant impact on the distribution of paleo-vegetation. The increase of coarse particles, the decrease of magnetic susceptibility, and the rising percentage of Gramineae, Artemisia and Chenopodiaceae pollen, all indicated that the paleoclimate became cooler and drier over the transitional period. Besides, we identified a cool event at about $76.8 \mathrm{ka}$ B.P. as revealed by grain-size curves, and in response to this event, the vegetation changed significantly but lagged several hundred years behind the grain size record. This study confirmed the cooling and drying tendency during the MIS 5 to 4 transition phase in the southern margin of the Chinese Loess Plateau. These findings shed light on the climatic change on vegetation evolution during the MIS 5 to 4 transition period.
\end{abstract}

Keywords: MIS 4; MIS 5; vegetation evolution; climate change; Chinese Loess Plateau

\section{Introduction}

The Chinese loess-paleosol sequence provides excellent records for reconstructing ecosystem evolution and monsoon climate variation during the Quaternary period. Especially for the last interglacial-glacial cycle, numerous studies have been conducted to explore the paleo-precipitation, paleotemperature, and paleo-vegetation type and evolution process [1-4].

Previous findings confirmed that the paleo-vegetation in the Chinese Loess Plateau (CLP) was semi-humid forest-grassland or semi-arid grassland that kept pace with the paleoclimate, while the 
climate was changeable over multiple cycles [5,6]. There was of great significance to carry out a study about vegetation type and its changing process during the climate transition period because of the inconstant paleoclimate. At present, global warming and its effect on ecosystems have become the focus of the current warming trend [7-10]. As for global cooling, most studies concentrated on the pre-Quaternary period [11-14], which took place frequently before and during the Pleistocene. However, pieces of geological and historical evidence showed that global cooling might take place and have a significant impact on agriculture and ecosystem $[15,16]$. Having in mind this knowledge gap, we chose a typical global cooling stage to explore vegetation evolution in relation to climatic oscillation, and the shift from Marine Isotope Stage (MIS) 5 to 4 was the optimal choice. This shift represented a transition from a typical warm-wet period to a cool-dry period, corresponding to the stratigraphic boundary between the first loess layer (L1) and the first paleosol layer (S1) in the Chinese Loess Plateau [17,18]. Moreover, stages MIS 5 and 4 were the closest typical warm and cool periods to now, with many previous studies for comparison [2-4].

For the MIS 5 to 4 transition, the methane record from the ice core named GISP2 revealed that it was characterized by an increase in continental ice volume [19]. While the ice-sheet expansion would result in stronger winter monsoon, which was the force of dust transportation, and it could lead to higher dust flux and richer coarse particles. The Chinese loess-paleosol deposits recorded this variation in detail along with vegetation evolution [20], and the boundary of MIS 5 to 4 in the loess-paleosol sequence was calculated around $73.9 \mathrm{ka}$ B.P. $[17,21]$. In the central CLP, the woody plants and C4 grasses decreased markedly during the MIS 5 to 4 transition, and this area was overwhelmingly dominated by arid steppe with minimal trees [22]. The high-resolution dolomite and calcite contents in loess and paleosol sequence exhibited an abrupt decrease in precipitation during the transition from MIS 5 to 4 [23], implying a rapid variation in the intensity of summer and winter monsoon. The existing studies for paleoclimate in the CLP displayed the instability and cooling trend during this transitional period.

Apart from central Asia, the cooling tendency could be detected in central and northern Europe as well. The sediment accumulation at Rhineland revealed a Europe-wide dust storm that occurred at the boundary between MIS 5 and MIS 4 [24]. The high-resolution pollen records showed that the transition from MIS 5 to 4 was characterized by an overall cold stage, with major shifts in winter precipitation and temperature, but summer temperatures were not so variable [25]. Besides the northern hemisphere, the southern hemisphere also showed a cooling trend during this transition. Pollen and fossil beetles in New Zealand revealed that the transition from MIS 5 to early MIS 4 was expressed as a swift change from a forest to grassland [26,27].

In brief, during the MIS 5 to 4 transition, the global cooling trend was confirmed by pollen assemblages, terrestrial deposits, and fossil records from many strata. Nevertheless, there are still some basic questions that remain unresolved, such as the climatic events and the adjustment process of the ecosystem during the transition.

In order to solve these problems, we conducted a high-resolution sampling in two typical profiles (Caijiapo, CJP, Yangling, YL) in southern CLP. We tested the basic physical and chemical properties of these loess-paleosol samples, along with pollen analysis for the two representative profiles and presented the high-resolution results at intervals of 2-cm to reveal climatic changes and ecological evolution in this region during the MIS 5 to 4 transition period. Based on extensive comparison of various proxy records from the two studied profiles, together with deep-sea sediment records, we discuss the mechanisms and processes involved in eco-environmental evolution and how they responded to monsoon transition in CLP at millennium-centennial time scales. The results might shed light on arranging the paleovegetation synthesis when we conduct the paleoecological reconstruction. 


\section{Materials and Methods}

\subsection{Study Sites and Samples}

In the sampling sites, the loess-paleosol sequence was intact, and no obvious erosion occurred to the L1 and S1 layers. We chose the CJP loess-paleosol sequence ( $\left.34^{\circ} 20^{\prime} 24^{\prime \prime} \mathrm{N}, 107^{\circ} 35^{\prime} 22^{\prime \prime} \mathrm{E}\right)$ and the YL loess-paleosol profile $\left(34^{\circ} 16^{\prime} 35^{\prime \prime} \mathrm{N}, 108^{\circ} 02^{\prime} 38^{\prime \prime} \mathrm{E}\right)$ to conduct this study (Figure 1). These two profiles are located in the southern margin of the CLP, which was considered as a sensitive zone to climate change as they documented the strength of East Asian summer and winter monsoons [28]. Although they are nearby profiles, the geomorphological unit is quite different: CJP profile lies on a highland (670 $\pm 4 \mathrm{~m}$ in altitude) and YL profile lies in a valley ( $477 \pm 5 \mathrm{~m}$ in altitude), which provides a good comparison of how geomorphology affected the paleo-ecosystems (Figure 2). The modern mean annual temperature and mean annual precipitation are around $13{ }^{\circ} \mathrm{C}$ and $650 \mathrm{~mm}$, respectively. The annual precipitation is mainly concentrated during the warm season from May to September. A total of 56 samples were taken from the two loess-paleosol sections at 2-cm intervals, which represented an age of about 70-78 ka B.P. with the estimation from an age model of Ding et al. [29]. In addition, in order to ensure the accuracy of this study, optically stimulated luminescence (OSL) dating was done as described below.

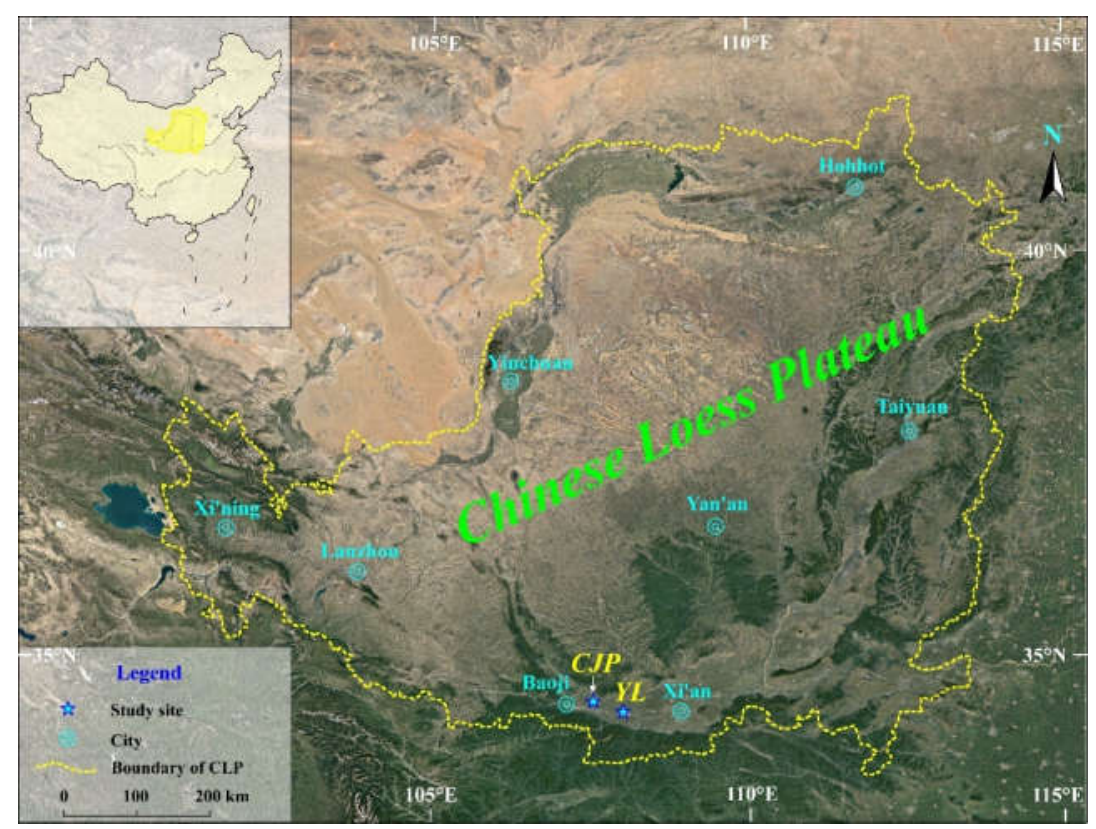

Figure 1. Schematic map of the study sites and their locations within the Chinese Loess Plateau (CLP). Two typical profiles, Caijiapo (CJP) and Yangling (YL), are located in the southern margin of CLP. 

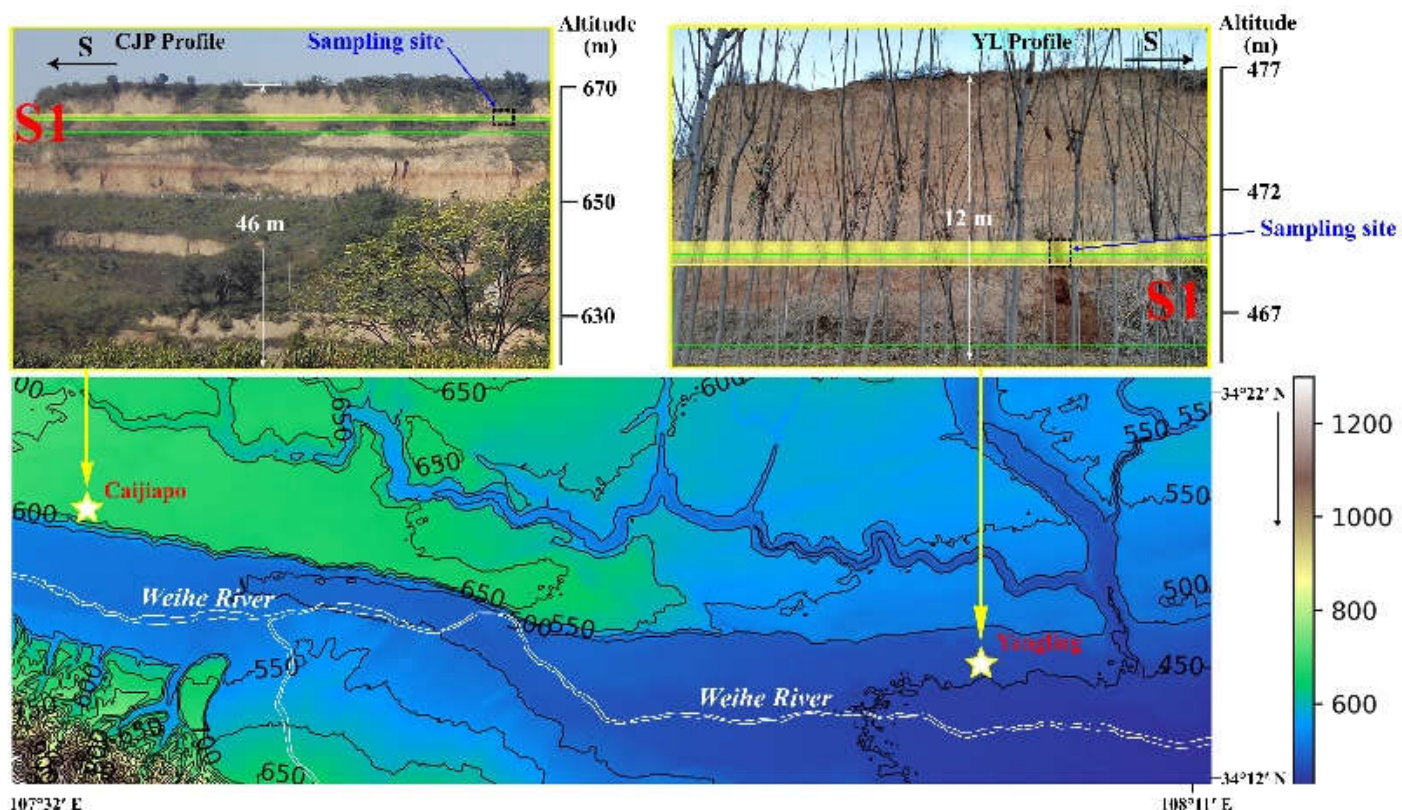

Figure 2. Terrain map (lower) and the overall landscapes of the two study profiles (upper). The green frames in the upper two photos showed the first paleosol layer (S1), and the two light yellow bands on the green frames show the study segment corresponding to Figure 3.

\subsection{OSL Dating}

During the transition period from MIS 5 to 4, by the weakening of the summer monsoon and the enhancement of the winter monsoon, the sedimentation rate was assumed to be evenly increased over time, so the age of each sample was calculated by interpolation and extrapolation [30]. The initial chronology of the CJP and YL section was established by linear interpolation using the ages of the S0/L1 boundary (11 ka, S0 is the Holocene paleosol), the S1/L1 boundary (73 ka), and the S1/L2 boundary (128 ka, L2 is the penultimate glacial loess) [29], together with OSL dating, as control points. The thickness of L1 and S1 was determined simultaneously to calculate the time span of each sample. OSL samples were collected using stainless steel pipes. The four samples were performed to determine the age of the section from $8.80 \mathrm{~m}$ and $9.00 \mathrm{~m}$ depth at Caijiapo profile and $9.15 \mathrm{~m}$ and $9.45 \mathrm{~m}$ at Yangling profile. OSL dating was conducted in the Laboratory of Neotectonics and Geochronology, Institute of Geology, China Earthquake Administration.

The pretreatment method proposed by Zhao et al. was applied to extract fine grains $(4-11 \mu \mathrm{m})$ and coarse grains $(90-125 \mu \mathrm{m})$ from the core of the collected samples [31]. Coarse grains were etched by hydrofluoric acid $(\mathrm{HF}, 40 \%)$ for $1 \mathrm{~h}$ to remove the polluted part of the feldspar and quartz crystals. Then, the fine-grains were treated with fluorosilicic acid $\left(\mathrm{H}_{2} \mathrm{SiF}_{6}, 35 \%\right)$ for $2-5$ days of corrosion. Afterwards, hydrochloric acid $(\mathrm{HCl}, 10 \%)$ was added for about $30 \mathrm{~min}$ to remove the fluoride precipitates.

The equivalent dose (De) values of all the samples were measured with a Risø TL/OSL-DA-20 reader (DTU Nutech, Denmark). The De values of fine-grained quartz $(4-11 \mu \mathrm{m})$ were measured using the Simple Multiple Aliquot-Regenerative Dose (SMAR) presented by Lu et al. [32]. The preheating status was $200-260^{\circ} \mathrm{C}$ for $10 \mathrm{~s}$, and the cut-heat temperature was $160^{\circ} \mathrm{C}$ for $10 \mathrm{~s}$. Irradiation was carried out by a ${ }^{90} \mathrm{Sr} /{ }^{90} \mathrm{Y}$ beta $(\beta)$-source built into the Risø Reader.

The concentrations of uranium $(\mathrm{U})$, thorium $(\mathrm{Th})$, and potassium $(\mathrm{K})$ were determined by the Neutron Activation Analysis (NAA) method. The dose rate value was obtained from the U, Th and K concentrations of the samples. Both the contribution of cosmic rays and the effects of water content were taken into consideration. The dose rate values of all samples were presented in Table 1. 
Table 1. Environmental radioactivity and dating results.

\begin{tabular}{cccccccc}
\hline $\begin{array}{c}\text { Sample } \\
\text { ID }\end{array}$ & $\begin{array}{c}\text { Depth } \\
(\mathbf{m})\end{array}$ & U (ppm) & Th (ppm) & K (\%) & $\begin{array}{c}\text { Dose Rate } \\
\text { (Gy/ka) }\end{array}$ & $\begin{array}{c}\text { Measured De } \\
\text { (Gy) }\end{array}$ & $\begin{array}{c}\text { OSL Age } \\
\text { (ka) }\end{array}$ \\
\hline CJP S1 -1 & 8.80 & $2.12 \pm 0.05$ & $11.70 \pm 0.27$ & $1.61 \pm 0.05$ & $3.10 \pm 0.18$ & $223.43 \pm 2.24$ & $72.19 \pm 4.24$ \\
CJP S1 -2 & 9.00 & $2.22 \pm 0.06$ & $13.86 \pm 0.31$ & $1.61 \pm 0.04$ & $3.27 \pm 0.20$ & $242.44 \pm 1.65$ & $74.12 \pm 4.58$ \\
YL S1 -1 & 9.15 & $2.60 \pm 0.04$ & $12.89 \pm 0.39$ & $1.72 \pm 0.02$ & $3.41 \pm 0.20$ & $249.77 \pm 2.81$ & $73.27 \pm 4.31$ \\
YL S1 -2 & 9.45 & $2.44 \pm 0.09$ & $13.55 \pm 0.06$ & $1.73 \pm 0.01$ & $3.52 \pm 0.21$ & $266.31 \pm 2.23$ & $75.61 \pm 4.47$ \\
\hline
\end{tabular}

${ }^{*}$ CJP S1 -1 represents the upper sample of S1 in CJP profile, CJP S1 -2 represents the lower sample of S1 in CJP profile,

YL S1 -1 represents the upper sample of S1 in YL profile, YL S1 -2 represents the lower sample of S1 in YL profile.

\subsection{Field and Laboratory Methods}

The Chinese loess-paleosol sequence played an important role in reconstructing the Quaternary climatic dynamics. Some physical or chemical parameters, e.g., stable carbon isotope, Magnetic susceptibility (MS), C3 and C4 plants, dolomite abundance and grain size, seem to be correlated well with the long-term variation in paleo-monsoons [4,14,32-35]. Considering the representativeness and commonality of the indexes, we selected the MS as a proxy for summer monsoon intensity, while coarse particles $(>63 \mu \mathrm{m})$ and the grain size ratio were sensitive to winter monsoon variations, being used to indicate the strength of winter monsoon [36]. Moreover, the SPECMAP and LR 04 (a 5.3-Ma stack of benthic $\delta^{18} \mathrm{O}$ records from 57 globally distributed sites published by Lisiecki \& Raymo in 2005) curves were applied in this study $[37,38]$, to compare our results with global paleoclimate records.

- Magnetic susceptibility:

MS was measured in situ using a portable MS meter (SM30, ZH Instruments, Brno, Czech Republic). We measured each profile at 2-cm intervals. Each sample was measured for three parallel times, and an average value was calculated. The measurement time was about $2 \mathrm{~s}$, giving an accuracy of $1 \times 10^{-7} \mathrm{~m}^{3} / \mathrm{kg}$ (SI unit).

\section{- Grain size:}

The pretreatment process of soil particle composition comprised of three steps. First, $10 \%$ hydrogen peroxide $\left(\mathrm{H}_{2} \mathrm{O}_{2}\right)$ was added to remove soil organic matter, then, $10 \%$ hydrochloric acid $(\mathrm{HCl})$ was added to remove carbonates, and finally, $0.05 \mathrm{~mol} / \mathrm{L}$ sodium hexametaphosphate $\left(\left(\mathrm{NaPO}_{3}\right)_{6}\right)$ was poured into the beaker to facilitate dispersion. The grain size of 56 samples from the two profiles was measured with a Mastersizer 3000 laser particle analyzer (Malvern Instruments, Malvern, UK) that automatically yields the percentages of clay, silt and sand size fractions and the median diameter of each sample, with an analytical precision of $1 \%$. Here, we selected the ratio of the fraction $<2 \mu \mathrm{m}(\%)$ to that $>10 \mu \mathrm{m}(\%)$ and the content of the sand-fraction $(>63 \mu \mathrm{m})$ as the winter monsoon intensity indexes [39], and the latter index was sensitive to wet-dry climate oscillations within the dust sources areas. The grain size was measured in the Key Laboratory of Arable Land Conservation (Middle and Lower Reaches of the Yangtze River), Ministry of Agriculture, Huazhong Agricultural University.

- $\mathrm{CaCO}_{3}$ content:

Loess and paleosol samples were air-dried and ground to pass through a $0.149 \mathrm{~mm}$ diameter sieve for measuring $\mathrm{CaCO}_{3}$ content using the calcimeter method [40]. $\mathrm{CaCO}_{3}$ content was analyzed in the key laboratory for geographical process analysis and simulation, Hubei Province, Central China Normal University.

\subsection{Pollen Sample Collection and Analysis}

All loess-paleosol samples were prepared using the heavy-liquid method [41]. Each sample $(30 \mathrm{~g})$ was treated with $10 \% \mathrm{HCl}$ and $10 \% \mathrm{NaOH}$ to dissolve calcareous minerals and remove the humic components. Pollen was concentrated using a heavy liquid solution $(\mathrm{KI}+\mathrm{HI}+\mathrm{Zn})$ with a 
specific-gravity. Finally, cellulose and humic debris were removed by acetolysis and fine sieving was applied to remove clay-sized particles. Pollen was identified and counted using $400 \times$ magnification under an Olympus microscope. Pollen analysis was conducted in the Institute of Hydrogeology and Environmental Geology, Chinese Academy of Geological Sciences.
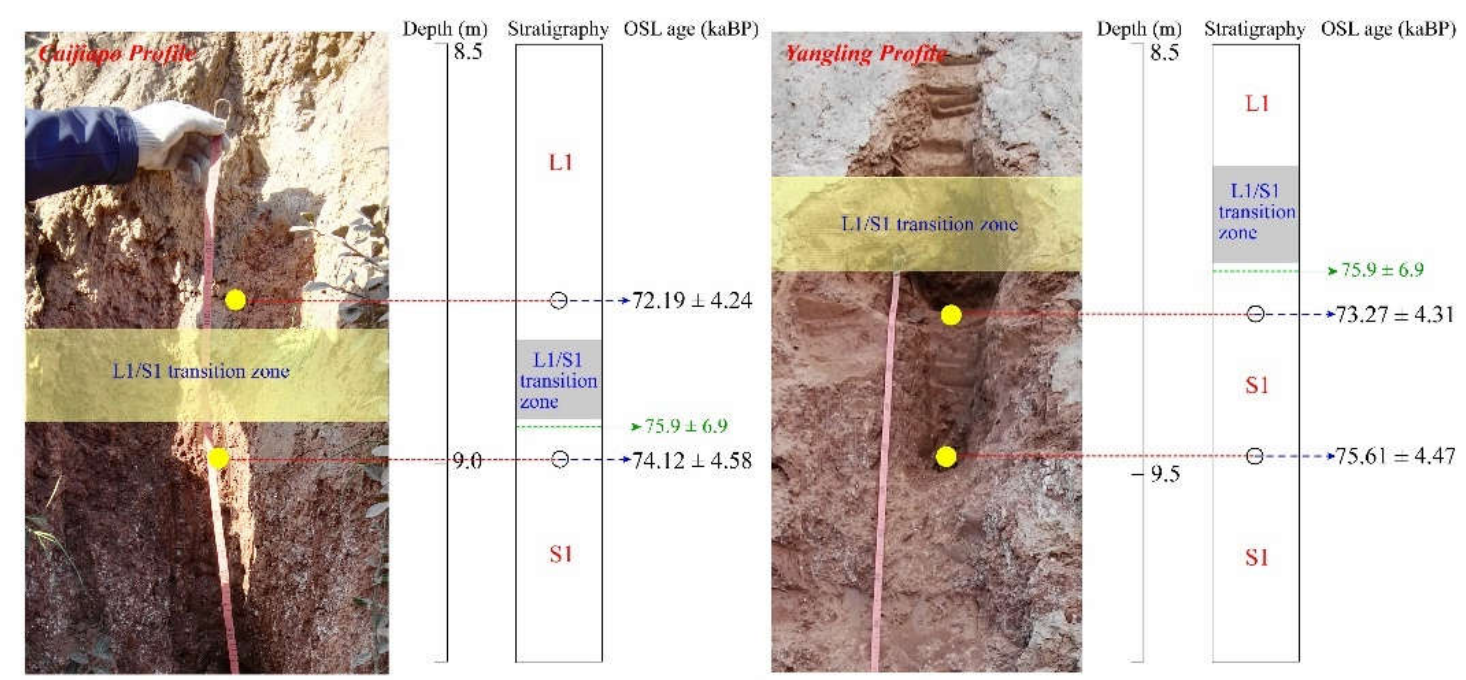

Figure 3. Photo of the first loess layer and first paleosol layer (L1/S1) transition zones in the Caijiapo profile (left) and Yangling profile (right). The optically stimulated luminescence (OSL) dating results are shown at the right of each profile photos (in black). The OSL data in green were the age of S1 at Weinan profile [42]. The photos of the entire profile from the ground surface down to over $10 \mathrm{~m}$ deep are shown in Figure 2.

Pollen percent diagrams were plotted using the software Tilia (version 2.1.1). Similarities between samples were calculated on the basis of pollen composition and expressed as log-transformed percentages. We only included in pollen diagrams and compositional analysis pollen taxa with abundances above $2 \%$ in at least two samples.

\section{Results}

\subsection{Luminescence Dating}

Data from OSL provided the age control for the loess-paleosol records and showed a good linear correlation with depth (Figure 3). Meanwhile, the result of Kang et al. was presented in this figure to support our data [42]. The correlation scheme was based on the age of the S1 top. This suggested the calculated further age model was credible. Based on field observations, laboratory tests, and OSL data, we are confident that the sampling profiles represented a time span of 70-78 ka B.P., which covered the transitional period from MIS 5 to 4 [29].

\subsection{Paleoclimate Indicator}

The results of the particle-size analyses are given in Figure 4. The grain size ratio (curves A and B) showed a decrease at about 76.8 ka B.P. (gray band c in Figure 4), while the coarse fraction $(>63 \mu \mathrm{m})$ (curves $C$ and $\mathrm{D}$ ) displayed a significant increase, and all the grain size curves indicated the strengthening of winter monsoon at about 76.8 ka B.P., namely, a cooling event occurred. Simultaneously, the LR 04 curve [38] (curve I) showed a relatively high value in $\delta^{18} \mathrm{O}$, which also exposed a cool event. Unfortunately, due to the lower time-resolution and limited accuracy, the SPECMAP [37] curve was almost a straight line, which can only demonstrate a cooling trend and no climatic event could be identified (so it is not introduced in Figure 4). After about $75.5 \mathrm{ka}$ B.P., there was a short period of warm-wet (orange band $b$ in Figure 4), with lower $>63 \mu \mathrm{m}$ fractions and higher grain size ratios, 
which illustrated a weakened winter monsoon and strengthened summer monsoon. However, the warm-wet event was an evanescent incident, that lasted only for about $1 \mathrm{ka}$, and then the cool-dry trend gradually and inevitably replaced the transitory warm stage. From about 74 ka B.P., the cooling trend in the southern margin of CLP coincided with LR 04, which confirmed the synchronization of climate change during the transition from MIS 5 to 4 . In addition, it is worth noting that, the amplitude of fluctuations in the CJP section was larger than that of the YL section.

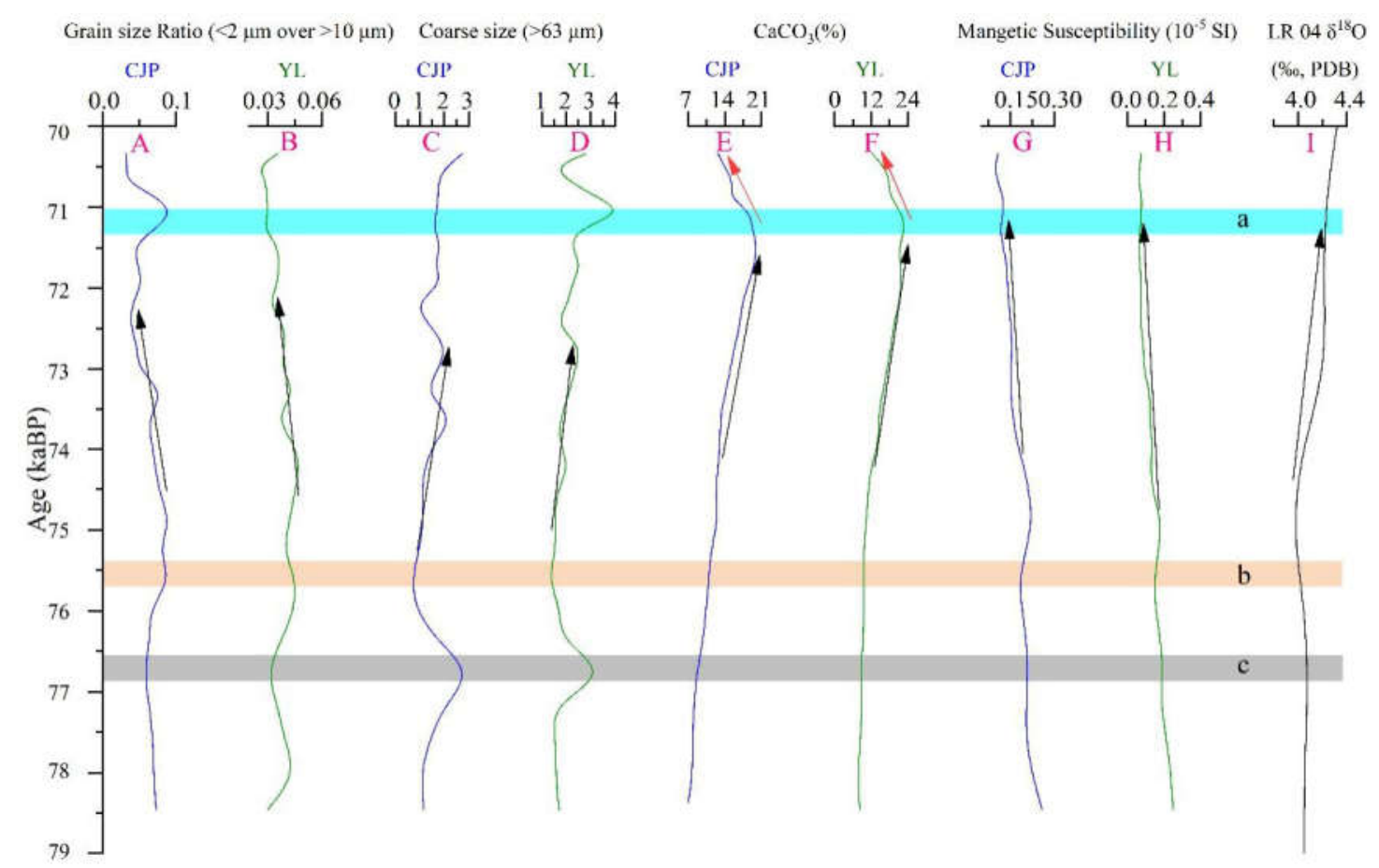

Figure 4. Monsoon indexes for the 70-78 ka period in the Caijiapo profile (CJP) and the Yangling profile (YL). " $A$ " and " $\mathrm{B}$ " are the grain size ratio of $<2 \mu \mathrm{m}$ over $>10 \mu \mathrm{m}$ of the two profiles, respectively; " $\mathrm{C}$ " and " $\mathrm{D}$ " are the coarse size of $>63 \mu \mathrm{m}$ of the two profiles, respectively; " $\mathrm{E}$ " and " $\mathrm{F}$ " are the content of $\mathrm{CaCO}_{3}$ of the two profile, respectively; " $\mathrm{G}$ " and " $\mathrm{H}$ " are the MS of the two profiles, respectively; " $\mathrm{I}$ " is the benthic foraminifera $\delta^{18} \mathrm{O}$ record from core LR 04 [38]. The three color-bands $\mathrm{a}, \mathrm{b}$ and c showed three climatic events: cool at about 71 ka B.P. (a), warm at about 75.5 ka B.P. (b), and cool at -76.8 ka B.P. (c), respectively. The black arrows in every curve between 75-72 ka B.P. showed the synchronous cooling trend by all indexes from A to I. The two red arrows in " $\mathrm{E}$ " and " $\mathrm{F}$ " showed the decreasing of $\mathrm{CaCO}_{3}$ content, indicated the warming trend after $71 \mathrm{ka}$ B.P.

The content of calcium carbonate $\left(\mathrm{CaCO}_{3}\right)$ and MS for the two profiles are also shown in Figure 4 . $\mathrm{CaCO}_{3}$ is a meaningful constituent of the loess-paleosol sequence on CLP, and its content as well as the formation of calcium silicate, are closely related to the climatic evolution [43]. However, in the CJP and YL profile, the $\mathrm{CaCO} 3$ curves almost increased smoothly from $4 \%$ to $20 \%$ and thereafter remained roughly at the high level of 12-24\% (curves $\mathrm{E}$ and F). There was hardly any fluctuation before $72 \mathrm{ka}$ B.P., and the overall trend was very similar to that of SPECMAP. Thus, no climatic events could be extracted from the section of 78-72 ka B.P. in curves E and F. In addition, an oscillation appeared (blue band an in Figure 4) at 71.6-70.5 ka B.P., and the $\mathrm{CaCO}_{3}$ content decreased from $20.1 \%$ to $12.7 \%$, indicating the increasing trend in precipitation during the cooling trend, however, this oscillation was not identified in the MS curves.

After the comparison of curves A-D with G-H (Figure 4), it was easy to visually discern that the fluctuation of grain size curves was more variable than that of MS curves, which indicated that MS was not as sensitive as grain size to paleoclimate changes [44]. Furthermore, this phenomenon also revealed that the signals of climate change were not well-imprinted in MS changes [45]. In this study, 
the MS curves only showed a decreasing tendency in the upper part, which could only be taken to confirm the cooling trend during the MIS 5 to 4 transition. Therefore, it was difficult to detect more detailed information on the paleoclimate change from the MS curves.

In short, the indicators in Figure 3 displayed the cooling or warm events during the transition from MIS 5 to 4 in the south margin of the CLP, which provided strong support for the instability of paleoclimate during the cooling process.

\subsection{Pollen Records and Paleo-Vegetation History}

Since the fossil pollen record has been widely accepted as a method for reconstructing the paleo-vegetation $[34,46,47]$, and in the CLP, the surface pollen assemblages could faithfully represent the modern vegetation [48]. It was reliable to analyze the paleo-vegetation of the study area by means of pollen assemblages. The studied pollen spectra can be subdivided into three pollen zones (PZ) (Figures 5 and 6) as follows:

- $\quad$ PZ-I (78.2-76.3 ka B.P.)

PZ-I (78.2-76.3 ka B.P.) is dominated by Compositae pollen in YL and Pinus pollen in CJP, with a few grains of Betula, Ulmus, Quercus, Aster and Monolete spores. Besides Compositae, Pinus forest might be the main arbor type in the study area. In addition to the above two, the relatively high amounts of Artemisia and Chenopodiaceae pollen may indicate that pigweed and artemisias were the co-dominant herb taxon; however, the pollen might have been partly produced by Gramineae. In this case, Gramineae was also co-dominant. Wet habitats with Ferns and S.sinensis were also common in the study area. The PZ-I pollen assemblages point to interglacial environmental conditions.

- $\quad$ PZ-II (76.3-73.0 ka B.P.)

PZ-II (76.3-73.0 ka B.P.) is dominated mostly by Compositae pollen in both profiles. Artemisia, Chenopodiaceae and Pinus are also abundant. Pollen concentration is lower than PZ-I. The lower sub-zone reveals that the paleoclimate became cooler and drier, and some plants migrated or disappeared. Herbs and pines dominated the area. Wet habitats with Taraxacum, Betula and Ulmus rarely grew here. Hippophae L increased at both profiles. According to the modern analogue methods, these pollen assemblages reflect sub-glacial environmental conditions with a slight deterioration in the middle sub-zone.

- $\quad$ PZ-III (73.0-70.3 ka B.P.)

PZ-III (73.0-70.3 ka B.P.) is characterized by the dominance of Compositae, Chenopodiaceae, and the appearance of Pinus in the upper subzone. The pollen concentration is relatively low due to climate change. We assume that this uppermost pollen zone developed during the MIS 4 when the study area was covered mostly by herbs in the south of the CLP.

Although the two profiles expressed a similar paleo-vegetation type and evolution process, some iconic species indicated that small-scale terrain features might have some influences on vegetation type. In the YL section, owing to the lower altitude and better water supply, the Artemisia and trees grew better; meanwhile, because of higher altitude and drier soil condition, the CJP profile was associated with more herbs and Compositae.

In summary, the paleo-vegetation record suggested by the pollen record shows a sequence of grassland vegetation with scattered trees and shrubs, being semi-forest for a short period, and a semi-arid grassland during the transition from MIS 5 to 4 . It is notable that Compositae pollen dominates all the spectra and no dense forest is identified in both sequences. In addition, it should be noted that the term "grassland" does not imply that Compositae was the only important element of the southern CLP vegetation. The pollen production rates for plants can vary enormously for every species [47], so it would be inappropriate to determine the vegetation type just by the calculation of the pollen ratios. 


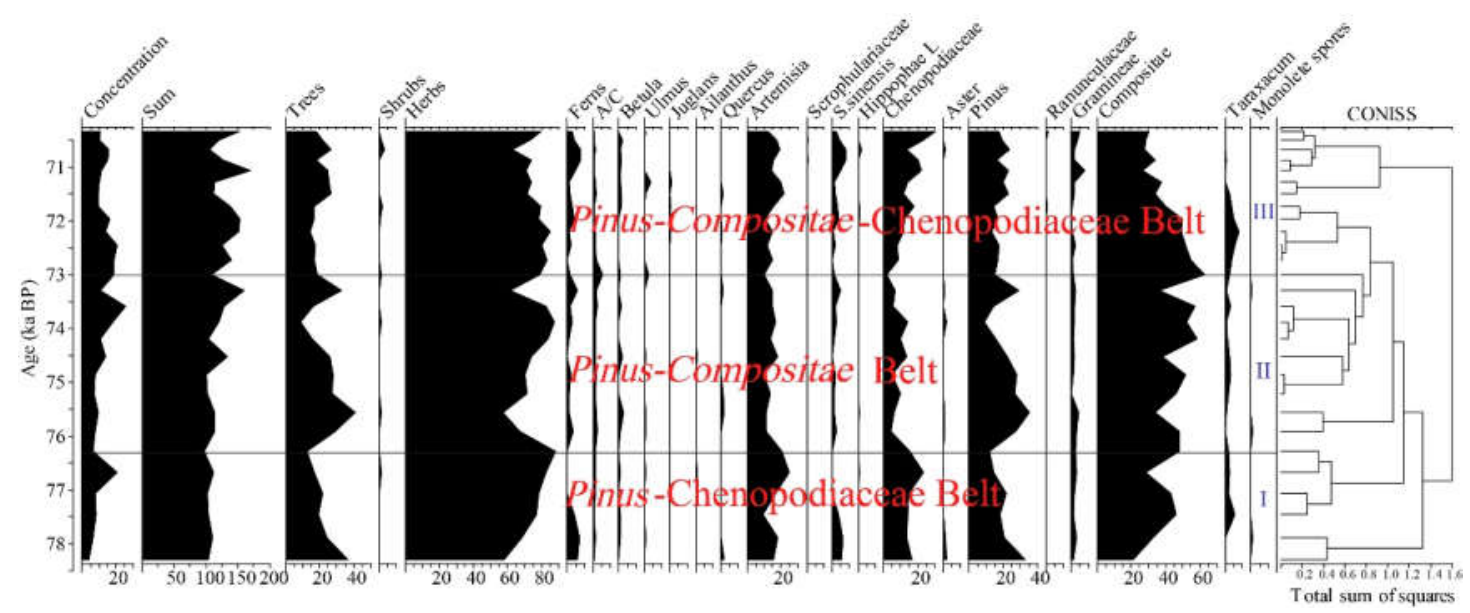

Figure 5. Pollen percentage diagram and cluster tree of the Caijiapo Loess-Paleosol sequence.

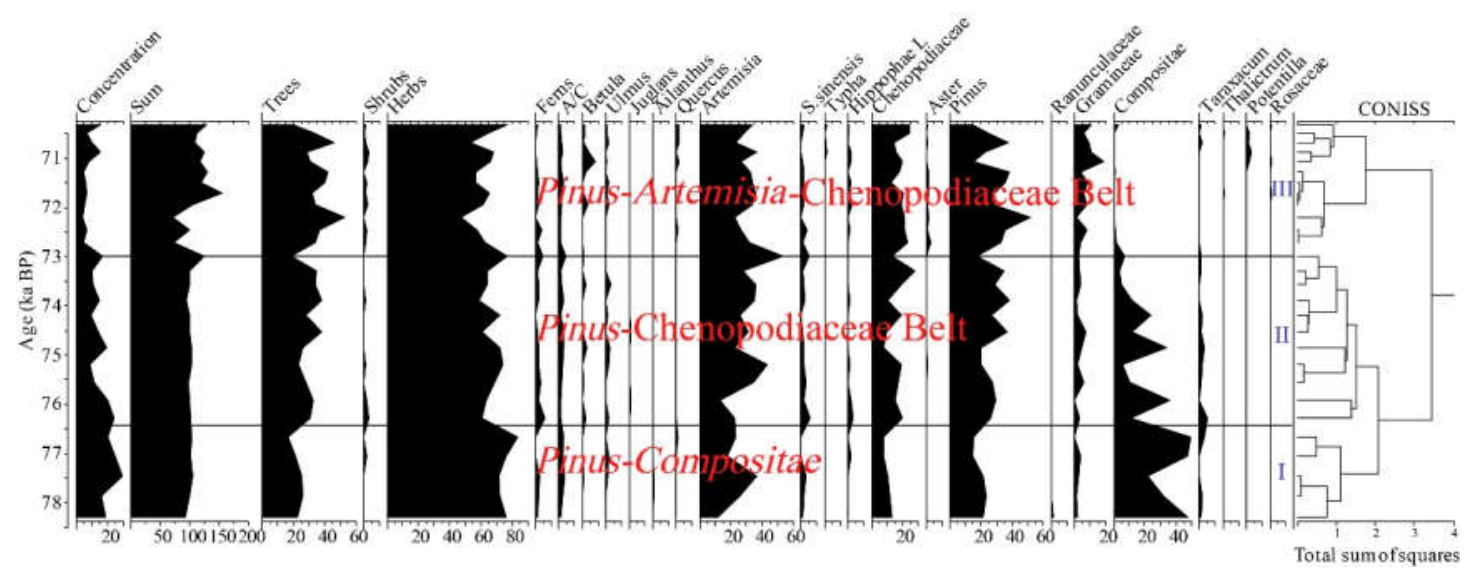

Figure 6. Pollen percentage diagram and cluster tree of the Yangling Loess-Paleosol sequence.

\section{Discussion}

\subsection{Pollen Type and Its Environmental Significance}

Pollen data revealed that the paleoclimate in the southern margin of CLP slowly became cooler and drier than the preceding period, and some abrupt climate shifts occurred during this transition. The pollen percentage results indicated the pollen assemblages were mainly controlled by soil moisture (linked to precipitation and terrain), though the temperature was also an important factor in controlling vegetation distribution. However, pollen data did not necessarily reflect the real-time status of the climate. It lagged behind the associated climatic changes. Davis and Botkin mentioned that the changes of the pollen records of cool-temperature climax forest are delayed by 100-200 years after climatic cooling, producing gradual vegetation adjustment in response to rapid climate changes, and reducing the amplitude of the response to the event of abrupt climate change [46]. As Figures 5 and 6 showed, in the transition from PZ-I to PZ- II, the increase in herbs and decrease in trees could be identified as dramatic precipitation and temperature decrease in the study area. This drastic environmental change might be the response to the 76.8ka B.P. event (Figure 4). It is noticeable that the extreme values do not exactly correspond to $76.8 \mathrm{ka}$ B.P., as the transition from PZ-I to PZ- II occurred at about 76.5 ka B.P., and lagged several hundred years after the cooling event. This result approximately agrees with a number of previous studies [49,50]. 


\subsection{Vegetation Type during the Transition of MIS 5 to 4}

The climate had some obvious effects on vegetation composition [22]. As mentioned earlier, the paleoclimate of MIS 5 was characterized as warm and wet, while MIS 4 was featured as cold and dry in the CLP $[2,3,17]$. Therefore, during the transition of MIS 5 to 4 , there should be significant changes in paleo-vegetation. However, as the pollen data shows (Figures 5 and 6), it is somewhat hard to convince oneself that there were evident changes in the vegetation during the study period. In order to verify the hypothesis that the vegetation type in the study area was statistically different between MIS 5 and MIS 4, a significance level of $\mathrm{P}<0.01$ was applied in this analysis. The result revealed that according to the pollen concentration, trees and herbs, as well as each family or genus detected in this study, significantly changed during this transition period (Table 2). Based on this result, we could discuss the sporo-pollen zones from MIS 5 to 4.

Table 2. Analysis of variance for pollen viability of CJP and YL profile during the MIS 5 to 4 transition.

\begin{tabular}{ccccccccc}
\hline \multirow{2}{*}{ Items } & \multicolumn{9}{c}{ CJP } & \multicolumn{3}{c}{ YL } \\
\cline { 2 - 9 } & SD & DF & $\mathbf{t}_{0.01}$ & T-Value & SD & DF & $\mathbf{t}_{0.01}$ & T-Value \\
\hline Concentration & 5.25916 & 27 & 2.771 & $12.40139^{* *}$ & 6.91493 & 27 & 2.771 & $10.04849^{* *}$ \\
Sum & 20.26788 & 27 & 2.771 & $31.91681^{* *}$ & 16.78813 & 27 & 2.771 & $33.63561^{* *}$ \\
Trees & 9.35853 & 27 & 2.771 & $15.14519^{* *}$ & 9.44568 & 27 & 2.771 & $18.50672^{* *}$ \\
Shrubs & 0.73733 & 27 & 2.771 & $2.81938^{* *}$ & 1.21499 & 27 & 2.771 & $4.66628^{* *}$ \\
Herbs & 18.78544 & 27 & 2.771 & $25.82411^{* *}$ & 14.84252 & 27 & 2.771 & $25.24854^{* *}$ \\
Ferns & 3.04703 & 27 & 2.771 & $5.89207^{* *}$ & 1.57191 & 27 & 2.771 & $6.01123^{* *}$ \\
Pinus & 8.23947 & 27 & 2.771 & $15.73424^{* *}$ & 9.11624 & 27 & 2.771 & $16.79153^{* *}$ \\
Betula & 0.79881 & 14 & 2.977 & $8.40398^{* *}$ & 1.51911 & 12 & 3.055 & $5.11208^{* *}$ \\
Ulmus & 1.13039 & 8 & 3.355 & $4.12837^{* *}$ & 0.72627 & 13 & 3.012 & $8.83176^{* *}$ \\
Gramineae & 2.53862 & 25 & 2.787 & $5.48496^{* *}$ & 4.56677 & 25 & 2.787 & $6.52751^{* *}$ \\
Chenopodiaceae & 9.68137 & 27 & 2.771 & $8.95977^{* *}$ & 6.0153 & 27 & 2.771 & $14.98587^{* *}$ \\
Compositae & 14.95018 & 27 & 2.771 & $17.97522^{* *}$ & 16.83916 & 20 & 2.845 & $4.78186^{* *}$ \\
Artemisia & 4.77912 & 27 & 2.771 & $20.60208^{* *}$ & 12.02907 & 27 & 2.771 & $13.44816^{* *}$ \\
Taraxacum & 2.85205 & 19 & 2.861 & $5.72335^{* *}$ & 1.18754 & 12 & 3.055 & $5.83874^{* *}$ \\
Aster & 0.48795 & 6 & 3.707 & $6.97137^{* *}$ & 0.5164 & 9 & 3.250 & $8.57321^{* *}$ \\
S.sinensis & 2.8109 & 22 & 2.819 & $6.67625^{* *}$ & 1.42032 & 21 & 2.831 & $7.50536^{* *}$ \\
\hline
\end{tabular}

SD: standard deviation, DF: degree of freedom. ${ }^{* *}$ Significant $(\mathrm{P}<0.01)$.

Vegetation types could be identified by pollen assemblages and soil properties in the study region. During the MIS 5 to 4 transition period, the overall pattern of paleo-vegetation was forest-steppe, and the preponderant arboreal tree was Pinus, followed by Ulmus and Betula. Despite this, trees were not so dense as herbs. Since during the last interglacial (MIS 5), which was characterized as warm and humid, the precipitation and soil water content could not sustain forest ecosystems in the CLP $[3,28,33,34,51]$. At the end of MIS 5, the paleoclimate turned to cool and dry, and the ecosystem was getting drier owing to the decrease of precipitation. Thus, the paleo-vegetation was dominated by grasses and herbs. According to the pollen composition and paleoclimate, herbaceous species like Artemisia, Hippophae L and Chenopodiaceae were more popular than trees in the study area. These plants could be classified as indicators for the semiarid environment [52,53], indicating a strengthened winter monsoon in the study area during the transition from MIS 5 to 4 . The results suggested that the pollen assemblages generally represent the paleo-vegetation composition and dominant taxa could be applied to the qualitative vegetation reconstruction in the southern margin of the CLP.

We also speculate the representation of several types through comparison of the abundance of each pollen taxon in the two pollen assemblages (Figures 5 and 6) with the zonal vegetation types and modern plant composition near the sample sites. Pinus pollens occurred in all the samples, even though few natural pine forests were found in the southern margin of CLP. This might be attributed to the long-distance transportation of Pinus pollen by the monsoon, suggesting the exaggerated representation 
of the Pinus pollen $[54,55]$. Therefore, although the percentage value of Pinus pollen in some samples exceeds $40 \%$, it does not mean that Pinus was the constructive species in a specified time and region.

Chenopodiaceae and Artemisia pollen were present with a relatively high ratio in the pollen samples and were seemingly over-represented [56]. Chenopodiaceae, Artemisia, and Gramineae pollen were characteristic of continental climates with the weaker summer monsoon and were used as indicators for climate changes [57,58]. However, Chenopodiaceae, Artemisia, and Gramineae were high pollen producers [59], the pollen percentage was not a direct credible index for the reconstruction of the terrestrial ecosystem and an indicator for the status of each species. However, the variability in the pollen count in the time direction could suggest the tendency of paleoclimate, especially in accordance with other indexes. As Figures 4-6 showed, in the wake of decreasing MS and increasing coarse particles, the Gramineae and Chenopodiaceae gradually increased. Therefore, the combination of these indexes well indicated the cooler and drier trend during the transition of MIS 5 to 4 .

\subsection{Geomorphological Location and the Paleo-Ecosystems}

From Figure 4A-D, we found that the grain size distribution curve of the CJP profile had a larger variation than that of the YL profile. This might be due to the effect of topography, which has a significant impact on the particle deposition [60]. The YL profile lies in the river valley, the deposition process there might have been more stable than that of the CJP profile located in the highland position.

Comparing Figures 5 and 6, we discovered that Typha distributed only in the YL profile. Previous research shows, that Typha is a marsh plant, thus it has been extensively cited as an indicator of humid environments [61]. Like Typha, Artemisia could indicate wet conditions too [62], as it was more plentiful in the YL profile than that in the CJP profile. Besides, as Compositae indicates dry soil conditions, they are widely distributed on the slopes and mountain areas [63]. As Figures 5 and 6 showed, during the transitional phase, Compositae was much richer in the CJP profile than that in the YL profile.

As mentioned earlier, the CJP profile is located on an upland, while the YL profile is located in the Weihe River valley (Figure 2), there is an altitude difference of nearly $200 \mathrm{~m}$ between these two locations. It is easy to infer that the soil is much wetter in the valley than that in the highland. Thus, the main reason for the absence of Typha pollen in the CJP profile might be the terrain features, which in turn affected the soil moisture. The distribution of Artemisia and Compositae might be due to a similar reason. This explanation, however, is based on the current status of landform, but how the paleo-terrain in the sampling sites at about $70 \mathrm{ka}$ ago is unknown. The distribution of Typha, Artemisia, and Compositae provided some pieces of supporting evidence that we could infer that during the transition of MIS 5 to 4, the topography of both the CJP and the YL profiles was close to their current state.

Weinan and Lantian sections, about 100-140 km away from the east of YL profile, demonstrated the similar vegetation types during the transition from MIS 5 to 4 . In the Weinan section, the pollen assemblages indicated that the vegetation was dominated by steppe, with sparse trees such as Betula and Pinus. The proportion of arid shrubs, especially Artemisia, increased with the cooler and drier climate [34,64]. In the Lantian and Weinan sections, the mean annual precipitation was around 400 $\mathrm{mm}$ during this transition period. The natural vegetations were shrub and grass, and forests were distributed sporadically on the highland $[2,65]$. The cooling trend did not change the vegetation types dramatically but intensified the arid and semi-arid ecosystems.

\subsection{Time Resolution and the Accuracy of OSL Ages}

During the climatic transition period, the aeolian dust flux, soil erosion and pedogenesis were constantly changing across time [32,36], and there was a positive relationship between grain-size distribution and deposition rate. In light of this assumption, a grain-size age model was put forward by Porter and An [17]. Subsequently, this model was repeatedly adopted and modified [66,67]. However, the "grain-size" model was questioned by a high-density OSL dating at Luochuan profile, and a Multiple Aliquot Regenerative-dose (MAR) method was proposed to obtain quartz OSL ages at the 
loess-paleosol section [21]. Unfortunately, the MAR method was based on high-density OSL dating and dose rate data. If we took the dating errors into account, it was meaningless to carry out a dense OSL sampling on such a short profile (the thickness is only $0.5-0.6 \mathrm{~m}$ ). Therefore, both the grain-size age model and MAR method were infeasible in this study. Due to the variability of the winter monsoon and continuous dust flux [35], we assumed that the deposition rate was increased gradually with the constantly enhanced winter monsoon during the transition of MIS 5 to 4 . Based on this analysis and reason, a linear interpolation method was introduced to calculate the time resolution of each sample. We resort to the timetable raised by Ding et al. [29], plus the OSL results, and compared with the pollen spectrum in the CJP and YL profiles, a new age model has thus been generated. The computing process was explained in detail in Section 2.2 of this paper. Although this method was also an imprecise one, the results correspond to the LR 04 data well. Therefore, it is confirmed that OSL dating is a credible method, which could meet the requirements of this study.

\section{Conclusions}

We present high-resolution results for basic sediment properties and pollen assemblages from two typical loess-paleosol sections in the Chinese Loess Plateau. During the MIS 5 to 4 transition period, the grain size ratio $(<2 \mu \mathrm{m}$ over $>10 \mu \mathrm{m})$, the coarse fraction $(>63 \mu \mathrm{m})$, and magnetic susceptibility indicated the enhancement of winter monsoon and the decline of the summer monsoon, which adequately characterized the transition from interglacial to glacial conditions. During the transition phase, the general paleo-vegetation type was forest-steppe. The pollen percentage of Gramineae, Artemisia and Chenopodiaceae rose gradually, which also indicated the cooling and drying trend. It is worthwhile to note that, a cooling trend was not proceeding smoothly. We detected an abrupt fluctuation at about $76.8 \mathrm{ka}$ B.P., and the ecological response lagged several hundred years after this abrupt climate change.

In addition, the topography had significant effects on dust deposition and paleo-ecosystems. Compared with the section of the river valley, the particle size distribution exhibited a more fluctuation and the vegetation communities are drier in the highland section. There are just two typical profiles studied here, and they are found close to each other. Besides, a more precise dating method would promote the accuracy of this study. Our subsequent work will concentrate on selecting additional typical sections and choose a better dating method in order to refine the reconstruction of climatic and vegetative change recorded in the loess-paleosol sequence in the region.

Author Contributions: Conceptualization, methodology, software, formal analysis, investigation, resources, data curation, writing-original draft preparation: T.W. and P.T. Writing-review and editing: H.W., H.L., T.Y., X.W., Y.J., and T.Y.; Project administration and funding acquisition: P.T. All authors have read and agreed to the published version of the manuscript.

Funding: The study was financially supported by the National Natural Science Foundation of China (41701323, 41907061 and 41771261) and State Scholarship Fund of China (201806775033). This study was also partially supported by the Fundamental Research Funds for the Central Universities (CCNU18QN003, CCNU18XJ048).

Acknowledgments: The authors appreciate Wanghai Tao for the draft of the graph (Figure 2), and Chunlei Zhao for improving the manuscript.

Conflicts of Interest: The authors declare no conflict of interest. 


\section{Symbols and Abbreviations}

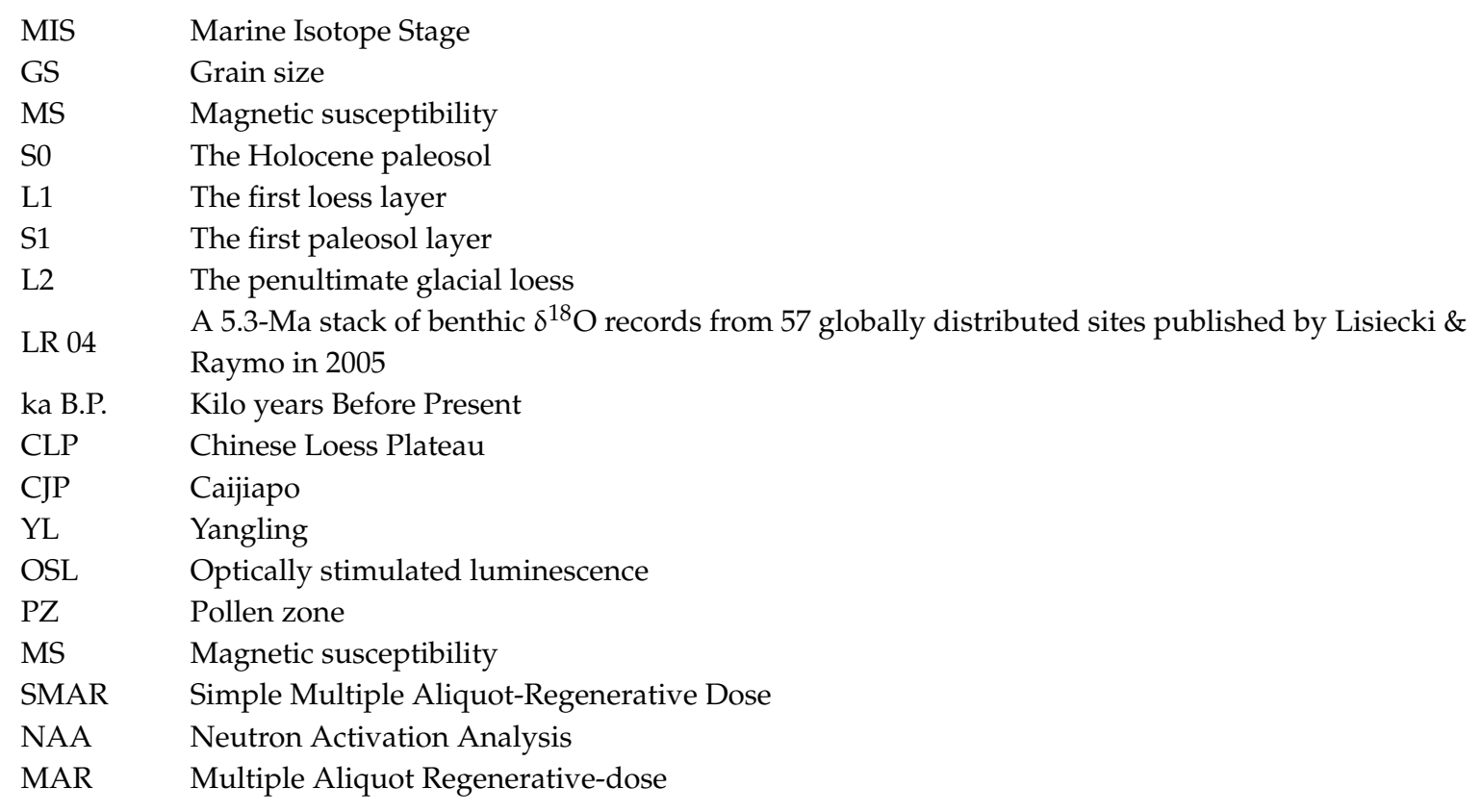

\section{References}

1. Lü, H.; Liu, T.; Guo, Z. Natural vegetation of geological and historical periods in Loess Plateau. Chin. Sci. Bull. 2003, 48, 411-416. [CrossRef]

2. Liu, W.; Yang, H.; Cao, Y.; Ning, Y.F.; Li, L.; Zhou, J.; An, Z. Did an extensive forest ever develop on the Chinese Loess Plateau during the past $130 \mathrm{ka}$ : A test using soil carbon isotopic signatures. Appl. Geochem. 2005, 20, 519-527. [CrossRef]

3. Jiang, W.; Cheng, Y.; Yang, X.; Yang, S. Chinese Loess Plateau vegetation since the Last Glacial Maximum and its implications for vegetation restoration. Appl. Ecol. 2013, 50, 440-448. [CrossRef]

4. Wang, X.; Cui, L.; Yanng, S.; Zhai, J.; Ding, Z. Stable carbon isotope records of black carbon on Chinese Loess Plateau since last glacial maximum: An evaluation on their usefulness for paleorainfall and paleovegetation reconstruction. Palaeogeogr. Palaeoclimatol. Palaeoecol. 2018, 509, 98-104. [CrossRef]

5. Wunsch, C.; Schmitt, R.W.; Baker, D. Climate change as an intergenerational problem. Proc. Natl. Acad. Sci. USA 2013, 110, 4435-4436. [CrossRef]

6. Bol'shakov, V.A. A link between global climate variability in the Pleistocene and variations in the Earth's orbital parameters. Stratigr. Geol. Correl. 2014, 22, 538-551. [CrossRef]

7. Root, B.; Price, J.; Hall, K. Fingerprints of global warming on wild animals and plants. Nature 2003, 421, 47-60. [CrossRef]

8. Sun, W.; Song, X.; Mu, X.; Gao, P.; Wang, F.; Zhao, G. Spatiotemporal vegetation cover variations associated with climate change and ecological restoration in the Loess Plateau. Agric. For. Meteorol. 2015, 209, 87-99. [CrossRef]

9. Mu, C.; Wu, X.; Zhao, Q.; Smoak, J.; Yang, Y.; Hu, L.; Zhong, W.; Liu, G.; Xu, H.; Zhang, T. Relict mountain permafrost area (Loess Plateau, China) exhibits high ecosystem respiration rates and accelerating rates in response to warming. J. Geophys. Res. Biogeosci. 2017, 122, 2580-2592. [CrossRef]

10. Anwar, T.; Kravchinsky, V.; Zhang, R.; Koukhar, L.; Yang, L.; Yue, L. Holocene climatic evolution at the Chinese Loess Plateau: Testing sensitivity to the global warming-cooling events. J. Asian Earth Sci. 2018, 166, 223-232. [CrossRef]

11. Ravelo, A.; Andreasen, D.; Lyle, M.; Lyle, A.; Wara, M. Regional climate shifts caused by gradual global cooling in the Pliocene epoch. Nature 2004, 429, 263-267. [CrossRef] [PubMed]

12. Liu, Z.; Pagani, M.; Zinniker, D.; DeConto, R.; Huber, M.; Brinkhuis, H.; Shah, S.; Leckie, M.; Pearson, A. Global cooling during the Eocene-Oligocene climate transition. Science 2009, 323, 1187-1190. [CrossRef] [PubMed] 
13. Herbert, T.; Lawrence, K.; Tzanova, A.; Peterson, L.; Caballero-Gill, R.; Kelly, C. Late Miocene global cooling and the rise of modern ecosystems. Nat. Geosci. 2016, 9, 843-847. [CrossRef]

14. Meng, X.; Liu, L.; Wang, X.T.; Balsam, W.; Chen, J.; Ji, J. Mineralogical evidence of reduced East Asian summer monsoon rainfall on the Chinese loess plateau during the early Pleistocene interglacials. Earth Planet. Sci. 2018, 486, 61-69. [CrossRef]

15. Stothers, R. The great Tambora eruption in 1815 and its aftermath. Science 1984, 224, 1191-1198. [CrossRef] [PubMed]

16. Brovkin, V.; Raddatz, T.; Reick, C.; Claussen, M.; Gayler, V. Global biogeophysical interactions between forest and climate. Geophys. Res. 2009, 36, L07405. [CrossRef]

17. Porter, S.; An, Z. Correlation between climate events in the North Atlantic and China during the last glaciation. Nature 1996, 375, 305-308. [CrossRef]

18. Xiao, J.L.; Porter, S.C.; An, Z.; Kumai, H.; Yoshikawa, S. Grain size of quartz as an indicator of winter monsoon strength on the Loess Plateau of central China during the last 130,000 yr. Quat. Res. 1995, 43, $22-29$. [CrossRef]

19. Brook, E.; Sowers, T.; Orchado, J. Rapid Variations in Atmospheric Methane Concentration during the Past 110,000 Years. Science 1996, 273, 1087-1091. [CrossRef]

20. Liu, T. Loess and the Environment; China Ocean Press: Beijing, China, 1985; pp. 60-65.

21. Lu, Y.; Wang, X.; Wintle, A. A new OSL chronology for dust accumulation in the last 130,000 yr for the Chinese Loess Plateau. Quat. Res. 2007, 67, 152-160. [CrossRef]

22. Zhang, J.; Ru, W.; Li, B. Relationships between vegetation and climate on the Loess Plateau in China. Folia Geobot. 2006, 41, 151-163. [CrossRef]

23. Meng, X.; Liu, L.; Balsam, W.; Li, S.; He, T.; Chen, J.; Ji, J. Dolomite abundance in Chinese loess deposits: A new proxy of monsoon precipitation intensity. Geophys. Res. 2015, 42, 391-398. [CrossRef]

24. Frechen, M.; Oches, E.; Kohfeld, K. Loess in Europe-mass accumulation rates during the Last Glacial Period. Quat. Sci. Rev. 2003, 22, 1835-1857. [CrossRef]

25. Helmens, K. The Last Interglacial-Glacial cycle (MIS 5-2) re-examined based on long proxy records from central and northern Europe. Quat. Sci. Rev. 2014, 86, 115-143. [CrossRef]

26. Moar, N.; Suggate, R. Vegetation history from the Kaihinu (last) Interglacial to the present, West Coast, South Island, New Zealand. Quat. Sci. Rev. 1996, 15, 521-547. [CrossRef]

27. Burge, P.; Shulmeister, J. An MIS 5a to MIS 4 (or early MIS 3) environmental and climatic reconstruction from the northwest South Island, New Zealand, using beetle fossils. J. Quat. Sci. 2007, 22, 501-516. [CrossRef]

28. Liu, W.; Huang, Y.; An, Z.; Clemens, S.; Li, L.; Prell, W.; Ning, Y. Summer monsoon intensity controls $\mathrm{C} 4 / \mathrm{C} 3$ plant abundance during the last $35 \mathrm{ka}$ in the Chinese Loess Plateau: Carbon isotope evidence from bulk organic matter and individual leaf waxes. Palaeogeogr. Palaeoclimatol. Palaeoecol. 2005, 220, $243-254$. [CrossRef]

29. Ding, Z.; Derbyshire, E.; Yang, S.; Yu, Z.; Xiong, S.; Liu, T. Stacked 26-Ma grain size record from the Chinese loess based on five sections and correlation with the deep-sea $\delta^{18} \mathrm{O}$ record. Paleoceanography 2002, 17, 1-21. [CrossRef]

30. Lu, H.; Yi, S.; Liu, Z.; Mason, J.; Jiang, D.; Cheng, J.; Stevens, T.; Xu, Z.; Zhang, E.; Jin, L.; et al. Variation of East Asian monsoon precipitation during the past $21 \mathrm{ky}$ and potential $\mathrm{CO}_{2}$ forcing. Geology 2013, 41, 1023-1026. [CrossRef]

31. Zhao, H.; Lu, Y.; Wang, C.; Chen, J.; Liu, J.; Mao, H. ReOSL dating of aeolian and fluvial sediments from Nihewan Basin, northern China and its environmental application. Quat. Geochronol. 2010, 52, 159-163. [CrossRef]

32. An, Z.; Kukla, G.; Porter, S.; Xiao, J. Late Quaternary dust flow on Chinese Loess Plateau. Catena 1991, 18, 125-132. [CrossRef]

33. Gu, Z.; Liu, Q.; Xu, B.; Han, J.; Yang, S.; Ding, Z.; Liu, T. Climate as the dominant control on C3 and C4 plant abundance in the Loess Plateau: Organic carbon isotope evidence from the last glacial-interglacial loess-soil sequences. Chin. Sci. Bull. 2003, 48, 1271-1276. [CrossRef]

34. Jiang, H.; Ding, Z. Temporal and spatial changes of vegetation cover on the Chinese Loess Plateau through the last glacial cycle: Evidence from spore-pollen records. Rev. Palaeobot. Palynol. 2005, 133, 23-37. [CrossRef]

35. Sun, Y.; Wang, X.; Liu, Q.; Clemens, S. Impacts of post-depositional processes on rapid monsoon signals recorded by the last glacial loess deposits of northern China. Earth Planet. Sci. 2010, 289, 171-179. [CrossRef] 
36. Porter, S. Chinese loess record of monsoon climate during the last glacial-interglacial cycle. Earth Sci. Rev. 2001, 54, 115-128. [CrossRef]

37. Berger, A.; Loutre, M. Insolation values for the climate of the last 10 million years. Quat. Sci. Rev. 1991, 10, 297-317. [CrossRef]

38. Lisiecki, L.; Raymo, M. A Pliocene-Pleistocene stack of 57 globally distributed benthic $\delta^{18} \mathrm{O}$ records. Paleoceanography 2005, 20, 1-17. [CrossRef]

39. Zeng, L.; Lu, H.; Yi, S.; Stevens, T.; Xu, Z.; Zhuo, H.; Yu, K.; Zhang, H. Long-term Pleistocene aridification and possible linkage to high-latitude forcing: New evidence from grain size and magnetic susceptibility proxies from loess-paleosol record in northeastern China. Catena 2017, 154, 21-32. [CrossRef]

40. Bascomb, C. A calcimeter for routine use on soil samples. Chem. Ind. 1961, 45, 1826-1827.

41. Zhang, Y.; Kong, Z.; Ni, J.; Yan, S.; Yang, Z. Pollen record and environmental evolution of Caotanhu wetland in Xinjiang since $4550 \mathrm{cal}$ a B.P. Chin. Sci. Bull. 2008, 53, 1049-1061.

42. Kang, S.; Lu, Y.; Wang, X. Closely-spaced recuperated OSL dating of the last interglacial paleosol in the southeastern margin of the Chinese Loess Plateau. Quat. Geochronol. 2011, 6, 480-490. [CrossRef]

43. He, W.; He, H.; Zhu, M. Calcium Nodules as a Proxy for Quaternary Paleoclimate Change on China's Loess Plateau. PLoS ONE 2015, 10, e0143928. [CrossRef] [PubMed]

44. Zhao, G.; Liu, X.; Chen, Q.; Lü, B.; Niu, H.; Liu, Z.; Li, P. Paleoclimatic evolution of Holocene loess and discussion of the sensitivity of magnetic susceptibility and median diameter. Quat. Int. 2013, 296, 160-167. [CrossRef]

45. Liu, W.; Yang, H.; Sun, Y.; Wang, X. $\delta^{13} \mathrm{C}$ values of loess total carbonate: A sensitive proxy for Asian summer monsoon in arid northwestern margin of the Chinese loess plateau. Chem. Geol. 2011, 284, 317-322. [CrossRef]

46. Davis, M.; Botkin, D. Sensitivity of cool-temperature forests and their fossil pollen record to rapid temperature change. Quat. Res. 1985, 23, 327-340. [CrossRef]

47. Odgaard, B.V. Fossil pollen as a record of past biodiversity. J. Biogeogr. 1999, 26, 7-17. [CrossRef]

48. Zhao, Y.; Li, F.; Hou, Y.; Sun, J.; Zhao, W.; Tang, Y.; Li, H. Surface pollen and its relationships with modern vegetation and climate on the Loess plateau and surrounding deserts in China. Rev. Palaeobot. Palynol. 2012, 181, 47-53. [CrossRef]

49. Menendez, R.; Megias, A.; Hill, J.; Braschler, B.; Willis, S.; Collingham, Y.; Fox, R.; Roy, D.; Thomas, C. Species richness changes lag behind climate change. Proc. Biol. Sci. 2006, 273, 1465-1470. [CrossRef]

50. Zhao, J.; Luo, X.; Ma, Y.; Zhou, Q.; Chen, B.; Yue, Y. Climate and soil moisture content during development of the first palaeosol in the southern Loess Plateau. Eur. J. Soil Sci. 2018, 69, 462-474. [CrossRef]

51. Zhao, Y. Vegetation and climate reconstructions on different time scales in China: A review of Chinese palynological research. Veg. Hist. Archaeobot. 2018, 27, 381-392. [CrossRef]

52. Liu, X.; Li, F.; Liu, D.; Sun, G. Soil organic carbon, carbon fractions and nutrients as affected by land use in semi-arid region of Loess Plateau of China. Pedosphere 2010, 20, 146-152. [CrossRef]

53. Li, C.; Li, Y.; Ma, J. Spatial heterogeneity of soil chemical properties at fine scales induced by Haloxylon ammodendron (Chenopodiaceae) plants in a sandy desert. Ecol. Res. 2011, 26, 385-394. [CrossRef]

54. Roy, I.; Ranhotra, P.; Shekhar, M.; Bhattacharyya, A.; Pal, A.; Sharma, Y.; Singh, S.; Singh, U. Over-representation of some taxa in surface pollen analysis misleads the interpretation of fossil pollen spectra in terms of extant vegetation. Trop. Ecol. 2018, 59, 339-350.

55. Bajpai, R.; Kar, R. Modern Pollen Deposition in Glacial Settings in the Himalaya (India): Abundance of Pinus Pollen and Its Significance. Palynology 2018, 42, 475-482. [CrossRef]

56. Liu, H.; Cui, H.; Pott, R.; Speier, M. The surface pollen of the woodland-steppe ecotone in southeastern Inner Mongolia, China. Rev. Palaeobot. Palynol. 1999, 105, 237-250. [CrossRef]

57. Rossignol-Strick, M. Sea-land correlation of pollen records in the eastern Mediterranean for the glacial-interglacial transition: Biostratigraphy versus radiometric time-scale. Quat. Sci. Rev. 1995, 14, 293-315. [CrossRef]

58. Wick, L.; Lemcke, G.; Sturm, M. Evidence of Lateglacial and Holocene climatic change and human impact in eastern Anatolia: High-resolution pollen, charcoal, isotopic and geochemical records from the laminated sediments of Lake Van, Turkey. Holocene 2003, 13, 665-675. [CrossRef]

59. Sun, X.; Luo, Y. Pollen record of the last 280 ka from deep sea sediments of the northern South China Sea. Sci. China Ser. D 2001, 44, 879-888. [CrossRef] 
60. Parker, S.; Kinnersley, R. A Computational and Wind Tunnel Study of Particle Dry Deposition in Complex Topography. Atmos. Environ. 2004, 38, 3867-3878. [CrossRef]

61. Chen, F.; Huang, X.; Zhang, J.; Holmes, J.; Chen, J. Humid Little Ice Age in arid central Asia documented by Bosten Lake, Xinjiang, China. Sci. China Ser. D 2006, 49, 1280-1290. [CrossRef]

62. An, C.; Feng, Z.; Barton, L. Dry or humid? Mid Holocene humidity changes in arid and semi-arid China. Quat. Sci. Rev. 2006, 25, 351-361. [CrossRef]

63. Wu, F.; Fang, X.; Ma, Y.; Herrmann, M.; Mosbrugger, V.; An, Z.; Miao, Y. Plio-Quaternary stepwise drying of Asia: Evidence from a 3-Ma pollen record from the Chinese Loess Plateau. Earth Planet. Sci. 2007, 257, 160-169. [CrossRef]

64. Sun, X.; Song, C.; Wang, F.; Sun, M. Vegetation history of the Loess Plateau of China during the last 100,000 years based on pollen data. Quat. Int. 1997, 37, 25-36. [CrossRef]

65. Ning, Y.; Liu, W.; An, Z. A 130-ka reconstruction of precipitation on the Chinese Loess Plateau from organic carbon isotopes. Palaeogeogr. Palaeoclimatol. Palaeoecol. 2008, 270, 59-63.

66. Lu, H.; Zhang, F.; Liu, X.; Duce, R. Periodicities of palaeoclimatic variations recorded by loess-paleosol sequence in China. Quat. Sci. Rev. 2004, 23, 1891-1900. [CrossRef]

67. Miao, X.; Hanson, P.; Stohr, C.; Wang, H. Holocene loess in Illinois revealed by OSL dating: Implications for stratigraphy and geoarchaeology of the Midwest United States. Quat. Sci. Rev. 2018, 200, 253-261. [CrossRef]

(C) 2020 by the authors. Licensee MDPI, Basel, Switzerland. This article is an open access article distributed under the terms and conditions of the Creative Commons Attribution (CC BY) license (http://creativecommons.org/licenses/by/4.0/). 